\title{
Cassava attractiveness in Nigeria: a policy improvement approach
}

\author{
Henry Egbezien Inegbedion \\ Department of Business Studies, Landmark University, Omu Aran, Nigeria \\ Emmanuel Edo Inegbedion \\ Department of Physical Planning, Nigeria Broadcast Academy, Lagos, Nigeria \\ Eseosa David Obadiaru \\ Department of Banking and Finance, Landmark University, Omu Aran, Nigeria \\ Abiola John Asaleye \\ Department of Economics, Landmark University, Omu Aran, Nigeria \\ Adebanji Ayeni \\ Department of Business Studies, Landmark University, Omu Aran, Nigeria, and \\ Charity Aremu \\ School of Post Graduate Studies, Landmark University, Omu Aran, Nigeria
}

\begin{abstract}
Purpose - The study examined policy improvement and cassava attractiveness. The purpose was to determine the optimum rewards using three strategies: selling of farm produce to harvesters, making wholesale of harvested outputs and retailing harvested outputs.

Design/methodology/approach - Three hundred and sixty (360) cassava farmers were surveyed in three local government areas in Edo South senatorial district of Nigeria. From their responses, probabilities were assigned to rewards for each strategy from each of the locations. Subsequently, dynamic programming was employed in data analysis. Specifically, Howard policy improvement technique was used to forecast expected rewards to cassava farmers in the three local government areas using the three strategies.
\end{abstract}

Findings - Cassava farmers in Edo South senatorial district of Edo stae, Nigeria, can maximize their earnings

from cassava by retailing at the local markets in Oredo and Egor local government areas and by making

wholesales at Ikpoba Okha local government area. Using this policy, they will realize approximately N2360 per

basin and approximately N33040 per plot of $1003100 \mathrm{ft}$. This will translate to N143724 per acre $(4.35$ plots of

$100 \mathrm{ft} 2)$.

Research limitations/implications - Availability of storage facilities as well as technical constraints to

cassava production.

Social implications - Provision of jobs to the unemployed, thereby reducing the level of unemployment in 
the country.

Originality/value - Suggestion of the sales strategy that will yield optimum returns to cassava farmers,

using policy iteration technique, and the projected estimates of the likely turnover when the strategy is adopted.

This is a point of departure from previous studies. Thus, the study used operations research methodology to

model solutions, through involvement in agriculture, to Nigeria's economic/financial problems, thus making it

unique. In broad terms the study demonstrates that investment in agriculture will help to reduce unemployment and enhance the country's national income. 